\section{Italian mafia accused of trafficking nuclear waste}

Italy's anti-mafia squad has launched an official investigation into allegations of illegal trafficking and disposal of nuclear waste - as well as clandestine production of plutonium - by managers of the Italian National Agency for New Technologies, Energy and the Environment (ENEA).

Eight former employees of ENEA's Trisaia research centre in the southern town of Rotondella, and two alleged members of the 'Ndrangheta mafia, are under suspicion following a decade-long inquiry. Trisaia is now a multidisciplinary research centre, but in the 1970s and 1980s it specialized in nuclear waste processing and storage.

A mafia informer told the anti-mafia bureau in Potenza that an ENEA manager paid the 'Ndrangheta mafia to get rid of 600 drums of nuclear and toxic waste from Germany, France, Switzerland and the United States in 1987. He claimed that the mafia disposed of the radioactive material at unauthorized, non-secure sites in southern Italy, Somalia and in the Mediterranean Sea. Investigators also suspect that the centre illegally produced plutonium during the 1980 s, which the mafia allegedly sent to Iraq. ENEA denies all charges and says that the centre did not have the capacity to produce plutonium. "But we will collaborate fully with the investigations to dispel any suspicion of misconduct," says its president, Luigi Paganetto.

\section{Scandinavian seals hit by deadly virus}

An unknown virus killed more than 2,300 seals around the Scandinavian coast this summer, local scientists reported last week. The death toll, currently about $14 \%$ of the population, is likely to rise further, they say.

The virus attacks the seals' respiratory systems. They suffocate in their own mucus,

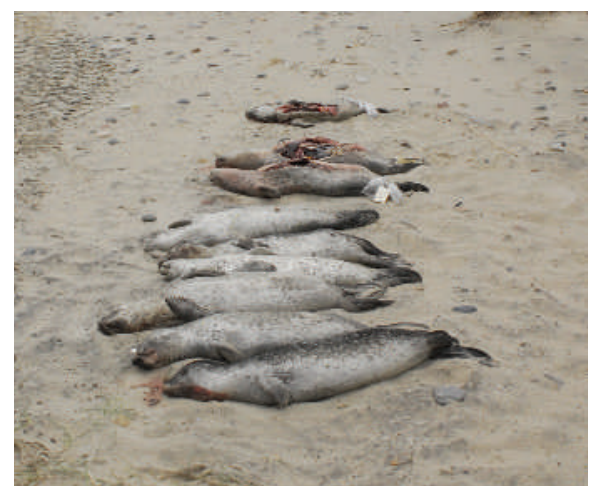

A mystery virus is killing Scandinavia's seals. and most die offshore. Scientists have recently seen breathing difficulties in some small dolphins in the area, suggesting the virus may also be infecting that species.

Tero Härkönen, a seal researcher at the Swedish Museum of Natural History in Kärna and his colleagues say the outbreak spread from the small Danish island of Anholt to the Skagerrak Strait, which flows between Denmark, Norway and Sweden - and then up to the Oslo Fjord.

A different virus attacked seals in Northern Europe in 1988 and 2002, wiping out about half of the population on each occasion. "The dynamics of the spreading of the two viruses are very similar," says Härkönen.

Virologists from the National Veterinary Institute in Uppsala, Sweden, are trying to identify the virus from samples taken from four dying seals.

\section{Earth scientists aim to gauge US thirst}

A US water census - the first in 25 years - could be on its way. The US Geological Survey has set a water audit as one of its decadal goals, noting that the issue will become more important as climate change alters water budgets.

Legislators have taken an initial step 